Article

\title{
Oversee and Punish: Understanding the Fight Against Corruption Involving Government Workers in Brazil
}

\author{
Fernanda Odilla \\ Faculty of Social Science and Public Policy, King's College London, London, WC2B 4BG, UK; \\ E-Mail: fernanda.figueiredo@kcl.ac.uk
}

Submitted: 15 December 2019 | Accepted: 17 February 2020 | Published: 28 May 2020

\begin{abstract}
This exploratory study leverages a major dataset of official penalties against Brazilian bureaucrats enforced between January 2003 and November 2014, when 5,005 expulsive sanctions were enforced, 68.5\% of which concerned acts of corruption. The analysis and discussion also integrate qualitative data gathered through 24 semi-structured interviews with civil servants who were integrity enforcers. Despite the rapid increase in the number of penalties enforced over the years, the creation of a robust set of disciplinary norms and an anti-corruption agency have not secured a fully operational horizontal accountability system within the executive. A great variance of corruption control was observed across agencies, manifested through disproportionate enforcement, not only of overall sanctions but also of corruption and noncorruption-related penalties. In light of the self-protective behaviour of civil servants, who openly say they do not feel comfortable in the role of corruption fighters, the article advances an argument on 'convenient accountability' - a kind of institutional abdication combined with a reluctance for peer monitoring, with outcomes that can be described as satisficing for integrity agents. This institutional aspect poses a risk to internal disciplinary systems and increases dependence upon external actors of accountability, compromising the efficiency of both.
\end{abstract}

\section{Keywords}

accountability; Brazil; bureaucracy; civil service; corruption; punishment

\section{Issue}

This article is part of the issue "Fighting Corruption in the Developed World: Dimensions, Patterns, Remedies" edited by Fabrizio Di Mascio (University of Turin, Italy) and Simona Piattoni (University of Trento, Italy).

(C) 2020 by the author; licensee Cogitatio (Lisbon, Portugal). This article is licensed under a Creative Commons Attribution 4.0 International License (CC BY).

\section{Introduction}

Understanding bureaucratic corruption is a challenge for researchers from different fields. Although one of the most straightforward approaches used to combat corruption comprises penalising illicit behaviour and rewarding integrity, there is still a significant need to better assess initiatives based on harsher sentences and greater incentives in the civil service (Gans-Morse et al., 2018, p. 174). The same applies to the analysis of the efficacy of anticorruption agencies and how they coordinate efforts to achieve competent oversight and punishment of potential wrongdoing within each governmental body.

Not only are studies on bureaucratic corruption control scarce, but those that do exist do not offer an optimistic outlook. They stress the risk of disciplinary con- trol exacerbating bureaucratic pathologies (Anechiarico \& Jacobs, 1996), and highlight that dismissal procedures can have detrimental effects by leading to more corruption (Fjeldstad, 2003) and undermining of staff morale (Davis, 2004). Severe penalties are also likely to have little effect when monitoring capacity is poor (Alt \& Lassen, 2014). With regard to rewards, existing empirical evidence suggests that adequate salaries are a necessary but insufficient condition for curbing corruption (Gans-Morse et al., 2018, p. 173).

It has been argued that enforcing policies to improve the motivation of public-sector workers could prove more efficient in fighting bureaucratic corruption than top-down monitoring or the enforcement of harsh sanctions (Gans-Morse et al., 2018). However, the idea that bureaucrats are guided primarily by professional norms 
and a sense of obligation to society (Perry, 1996; Perry \& Hondeghem, 2008), setting aside their own individual interests, defies the models that show public officials to be self-interested individuals (Brennan \& Buchanan, 1985; March \& Olsen, 1989) who attempt to maximise career success (Geddes, 1994) when choosing policies and making decisions. Thinking about the costs and benefits as perceived by those responsible for enforcing the anti-corruption apparatus helps to clarify the factors that could compromise the effectiveness of more rules, procedures and organisational changes in the fight against corruption.

With the broad aim of apprehending the perceived incentives for and constraints upon anti-corruption measures within the civil service, this article examines the official response to bureaucratic corruption, focusing on the issue of peer monitoring. The narrower goal is to identify trends so that future research can use this information to better understand bureaucratic corruption and the likely effectiveness of initiatives aimed at controlling it. This study is, therefore, an exploratory attempt to uncover the dynamics behind administrative penalties for corruption by examining descriptive statistics for the sanctions enforced and through interviews with 24 integrity enforcers. It uses the Brazilian federal executive and the work of its anti-corruption agency, the Office of the Comptroller General (Controladoria Geral da União), as a case study of disciplinary action.

Although this study advocates that corruption is "the abuse of a trust, generally one involving public power, for private benefits which often, but by no means always, come in the form of money" (Johnston, 2005, p. 11), for methodological reasons the analysis of the data presented in this thesis restricts itself to the Office of the Comptroller General's typology of corruption, which is limited to administrative legal types (see Supplementary File). The theoretical framework presented in the next section draws on principal-agent theory to explore the phenomenon of collusion as an attempt to understand which factors, other than the actual wrongdoing that integrity enforcers are tasked with investigating, are taken into consideration by those enforcers when holding their peers accountable. The rationale here is that governmental bodies responsible for imposing ethical behaviour and disciplinary control may sometimes be selective in terms of actions and targets, due to the external and internal demands and interests to which these bodies and their integrity enforcers are exposed (Vasconcellos de Figueiredo, 2016).

Accountability is very likely to be enforced in a way that reduces costs, difficulty and inconvenience for the integrity enforcers themselves. The result is less-thancomplete accountability, which this study refers to as a manifestation of 'convenient accountability.' It is assumed that manifestations of convenient accountability are more likely to be found when government branches are supposed to hold themselves accountable, and especially when offenders and enforcers are colleagues, as is the case in the Brazilian executive branch. This study also expects that corruption-related procedures are more likely to involve convenient accountability, as they may be perceived as more complex and costlier to investigate when compared, for example, to abandonment of office or frequent absence, which also result in the expulsion of civil servants in Brazil.

The article then presents the data and methods. Following that, the evolution of the Brazilian accountability mechanisms and how disciplinary and criminal sanctions interact in the Brazilian context are discussed. Based on what has already been observed in the public service in Latin America (Geddes, 1994; Gingerich, 2013; Grindle, 2012), this study expected to find fragile and incomplete institutionalisation of the recent reforms to the Brazilian disciplinary system, particularly those made since the Office of the Comptroller General was created in the early 2000s to coordinate anti-corruption efforts in the federal executive.

The findings revealed a large cross-agency diversity in the effectiveness of anti-corruption mechanisms, manifested through disproportionate enforcement, not only of overall sanctions but also of corruption- and noncorruption-related penalties. The interviews suggested that even when formal rules and internal affairs units have been established, oversight and punishment are more likely to be enforced if outcomes are convenient for integrity enforcers themselves. This aspect of institutional design poses a clear risk to internal disciplinary systems and increases dependence upon external actors of horizontal accountability, compromising the efficiency of both. Although this article contributes to the debate on bureaucratic corruption by exploring constraints on peer monitoring and their possible impact on the issuing of official penalties, it concludes by suggesting further research with more robust models and empirical evidence to ensure more credible and consistent anti-corruption monitoring and enforcement.

\section{Theoretical Foundations}

Previous studies on corruption and bureaucracy emphasise that the quality of public administration, especially professionalisation and autonomy-the independence of bureaucrats from political principals-is an important determinant of corruption (Bersch, Praça, \& Taylor, 2016; Loureiro, Abrucio, \& Pacheco, 2012; Meyer-Sahling \& Mikkelsen, 2016; Oliveros \& Schuster, 2017; Treisman, 2000). These studies point out, in particular, the positive impact of recruitment on merit in terms of reducing corruption (Dahlström, Lapuente, \& Teorell, 2012; Rauch \& Evans, 2000). But unfortunately they have not shed light on control and the implementation of disciplinary sanctions as deterrents for corruption.

Although it is assumed that the degree of deterrence can decrease sharply if law enforcement is flawed (Becker \& Stigler, 1974), very little is said about the willingness of and incentives for integrity enforcers 
to enforce policies or, as addressed in this study, to monitor, conduct investigations, and suggest sanctions against their own peers, as in Brazil. Agency theory has emphasised the benefits of peer monitoring, suggesting it can increase performance and the chances of detecting misconduct and inappropriate behaviour (Laffont \& Meleu, 1997; Loughry \& Tosi, 2008; Stiglitz, 1990). Self-policing would solve problems related to self-interested behaviour and asymmetric information. Loughry and Tosi $(2008$, p. 877) point out that, under agency theory, agents are assumed to be both effortand risk-averse, and may be opportunistic in the pursuit of their self-interest. Agents also often have better information than principals, which allows them to conceal their actions. From the classical principal-agent perspective, rulers are the principals and bureaucrats the agents (Rose-Ackerman, 1978; van Rijckeghem \& Weder, 2001).

Peer monitors, however, can potentially face issues related to self-interested behaviour. The concern that bureaucrats might identify with interest groups rather than serve the public interest (Geddes, 1994; Tirole, 1993) should also be extended to integrity enforcers. The phenomenon of collusion, in which behaviour is better predicted by the analysis of group as well as individual incentives (Laffont \& Rochet, 1997; Tirole, 1993), is a theoretical framework that has been expanding fast within the field of organisation studies. Collusion theory provides a set of insights to understand how civil servants hold themselves accountable.

Lessons from Latin America, in particular, suggest that civil service reforms aimed at building up a more professional and responsible corps involve years and sometimes decades of conflict, mainly with supporters of patronage, and are by no means assured of success by the passing of a law or the creation of a new institution (Grindle, 2012, p. 11). While discussing the struggle over reforms that were intended to increase state capacity, Geddes states that "levels of competence, efficiency and honesty have varied widely within the Brazilian democracy" (Geddes, 1994, p. 20). In such settings, not only the politicisation of bureaucracy but also electoral rules have important consequences for the efficacy of corruption networks (Gingerich, 2013, p. 48).

Although this article does not focus on the significant overlap between political and bureaucratic careers in Brazil, as Gingerich (2013) competently does, it explores latent variables related to corruption control, evaluated by the author through survey data from interviews with civil servants in Brazil, Chile and Bolivia. In a slightly different vein from Gingerich's work, this exploratory study also considers internal controls, the likelihood of being investigated and the likelihood of dismissal when analysing the distribution of administrative penalties, and investigates the perceived costs and benefits of peer monitoring.

The aforementioned theories make it possible to argue that the legal settings and disciplinary control mechanisms often ignore the probability of increasing the cost of control and promote collusion or a high level of reliance on external accountability enforcers. It cannot be assumed that integrity enforcers are always competent and motivated to enforce accountability, even when the institutional apparatus is updated and checks-andbalances mechanisms exist on paper. In public organisations, holding civil servants and politicians accountable involves effort, difficulties, and many inconveniences.

It can be expected, therefore, that state agencies responsible for imposing ethical behaviour and disciplinary control may sometimes be selective in terms of actions and targets, due to the external and internal demands and interests to which they are exposed (Vasconcellos de Figueiredo, 2016). This article aims to explore whether there is a variation of sanctions for corruption and other serious administrative offences and, if so, to look for evidence to support the theory that this is due to the perceived high costs of oversight and punishment mechanisms from the enforcers' point of view.

As Samuel P. Huntington stated when talking about democracy, a "value which is normally good in itself is not necessarily optimised when it is maximised" (1989, p. 33). This is also the case of accountability from the perspective of integrity enforcers. Because of a series of considerations other than the wrongdoing of those investigated, accountability is only enforced to certain extents, or in a form that reduces perceived costs and avoids uncomfortable conflicts for integrity enforcers. The concept of 'convenient accountability' is defined as constraints on accountability as a result of the tendency on the part of those who are supposed to uphold integrity and/or deter misconduct ('integrity enforcers') to choose actions and/or targets that are convenient for them. The result is partial enforcement, i.e. neither total impunity nor complete accountability.

'Accountability' is defined here as a system of internal and external checks and balances aimed at ensuring that duties are properly carried out and individuals held responsible if they fail to do so (Bovens, 2007; Fox, 2007; Macaulay, 2002; O'Donnell, 1999). 'Integrity agents' refer to those entitled to design, monitor and enforce normative and other safeguards to uphold integrity and/or deter misconduct by monitoring, investigating and punishing. In addition, the concept of convenient accountability builds on several existing definitions of accountability, in which state agencies oversee and sanction public officials (Fox, 2007; Mainwaring \& Welna, 2003; O'Donnell, 1999; Vasconcellos de Figueiredo, 2016) while aiming to focus attention on the mechanisms of control and punishment and to emphasise how the enforcement of accountability can be subjective and limited in practical terms.

This study expects to find stronger manifestations of convenient accountability in regard to corruption-related procedures as it may be more time-consuming and difficult to collect material evidence in such cases compared to other serious offences. Administrative sanctions for corruption-related cases necessarily result in dismissals or cancellations of pension and criminal procedures may 
be initiated against the bureaucrat under suspicion. In addition, the constraints on accountability are more likely to be found in agencies with less mature and less organised internal affairs departments and fewer dedicated personnel, and which depend to a great extent on other civil servants to carry out disciplinary procedures. This increases the proximity between the investigators and those being investigated, and consequently produces more constraints.

\section{Data and Methods}

This study can be seen as exploratory due to the scarcity of other research that has used disciplinary sanctions against civil servants as the main object of analysis when assessing bureaucratic corruption control. In Brazil, the list of all the dismissals, demotions, and cancellations of pension that were enforced as punishments-along with the full name of the civil servant, the agency and state where they were working, and the date when the punishment was published in the federal government official gazette-is available to the public on the federal government transparency website (Portal da Transparência Brasil, 2020).

In response to my formal request by email in 2014, the Office of the Comptroller General provided the same list available online with additional information on those punished, such as the social security number, the title of the position the individual held, the procedure number, and the laws and norms that were violated, which indicate whether the act can be categorised as corruption. The time period covered was January 2003 to November 2014. From the Personnel Statistics Bulletin, a report released monthly and openly accessible on the Ministry of Planning website, it was possible to gather information on the general figures regarding the federal civil service, such as the size of workforce and annual expenditure on salaries.

Unfortunately, no data were available for those cases in which civil servants were acquitted after being investigated or had their case closed without any sanction being enforced for any other reason. The quantitative dataset is thus limited to enforced cases (civil servants who were caught and punished) and it only encompasses civil servants working directly for the central government in ministries, governmental bodies, foundations, and regulatory agencies who were sanctioned for engaging in bureaucratic misconduct.

Descriptive statistics was complemented with 24 interviews with civil servants responsible for designing anti-misconduct measures and for investigating their colleagues and recommending sanctions against them. This study used a convenience sample and respondent-driven samples, i.e., non-probability sample, but an easily selectable subset of a hard-to-reach population, in this case of civil servants directly involved in the creation and functioning of the disciplinary system. When accessibility is an issue and materials are sensitive, non-probability sam- ples are easily acceptable and applicable (Bryman, 2008) and can provide asymptomatically unbiased estimates (Salganik \& Heckathorn, 2004).

The 24 interviewees comprised individuals who had decision-making power and participated in the creation and consolidation of the Office of the Comptroller General, leaders who helped to design corruptionmonitoring measures, and people with experience in monitoring the disciplinary system and conducting disciplinary procedures. Several respondents had direct experience with more than one initiative. The ones with expertise in corruption-monitoring were selected on the basis of the number of sanctions enforced by each governmental body. Accordingly, participants were those who were working or had worked directly for internal affairs units, or were part of disciplinary punitive committees (Administrative Disciplinary Procedures), or who were responsible for monitoring the disciplinary system from the Office of the Comptroller General in agencies/ministries with (i) a high number of corruption-related sanctions (Social Security, Justice, Finance, Environment, Labour and Employment, Integration, and Office of the General Attorney); (ii) a medium number of corruption-related sanctions (Health, Defense, Mining and Energy, and Communications); and (iii) a low number of corruption-related sanctions (Foreign Affairs, Sports, Cities, Science and Technology, and Social Development). The Supplementary File gives general information on the interviews and interviewees, who cannot be identified, in accordance with the King's College London Research Ethics Subcommittee's authorisation to this study (Reference Number HR14/150795).

The interviews, which were conducted in Portuguese, combined a pre-determined set of questions with open and prompted questions using prompting and probing (Bryman, 2008; Fielding \& Thomas, 2001). The interviewees were first asked to talk about their career path and how they started working in the disciplinary system. Then, the perceived costs, constraints and incentives in creating rules and in investigating their own peers for corruption and other offences were discussed, followed by the most common type of defendant and offences, and the major issues and qualities of the Brazilian disciplinary system. Finally, they were showed and asked to comment on figures and tables separating corruption-related and non-corruption related offences. The average duration of the interviews was 1 hour 10 minutes and the overall duration of the recorded material was approximately 28 hours.

The analysis of how the same questions were addressed allowed me to identify certain traits and topics repeated by the respondents. In this exploratory study, the analyses of the interviews were initially made through deductive and inductive coding (Boyatzis, 1998). Following that, particular themes and the different approaches to them were analysed, considering the role and the governmental body of the interviewee in order to identify patterns and evaluate the participants' answers. 


\section{Research Context: Controlling Bureaucracies in Brazil}

In Brazil, it is only since the 1930s-through three broad administrative reforms aiming to professionalise the state bureaucracy and to guarantee economy and efficiency-that control mechanisms focused on internal disciplinary procedures and sanctions have gained a more robust and normative form. In addition, since the 1988 Constitution, Brazil has had a web of accountability (Mainwaring \& Welna, 2003; Power \& Taylor, 2011) with internal and external agencies whose attributes compete with and complement each other. Despite the legal apparatus, which looks strong on paper, it was nevertheless the case that for decades those in power and in public positions at all levels were very likely to indulge in acts of corruption with little fear of sanction, as enforcement mechanisms were ineffective and the punitive system was not closely monitored.

A specific anti-corruption agenda within the civil service was introduced only in the mid-1990s and early 2000s. Before 1994, for example, Brazil had no formal public ethical guidelines for civil servants, apart from the criminal code and civil service statute (Fleisher, 2002). In 2001, the federal executive created an internal affairs department to investigate and punish civil servants more rapidly: the Office of the InspectorGeneral (Corregedoria Geral da União). This agency was President Fernando Henrique Cardoso's personal political response to 16 corruption scandals in his government in order to avoid several inquiry committees in congress (Fleisher, 2002). In 2003, under President Luiz Inácio Lula da Silva's administration, the agency started its second phase, gaining a new name-the Office of the Comptroller General (Controladoria Geral da União)and 'anti-corruption' and transparency as formal, written attributes.

Lula's Workers' Party (Partido dos Trabalhadores) came to power waving an anti-corruption banner, although in government it would face various corruption scandals and inquiry committees in congress. The Office of the Comptroller General under Lula, however, was endowed with a stronger structure and a more qualified workforce. It also became an agency directly linked to the presidency, fulfilling both administrative and advisory roles. The Office of the Comptroller General became the most important federal executive auditing, discipline enforcer, and anti-corruption agency, gaining the status of a cabinet ministry, which meant more freedom to use the public budget, to select and train its own civil servants, design bills, and enforce its own plans of action. However, the head of the Office of the Comptroller General continues to be appointed by the president and since 2014 the agency has had a limited budget.

In January 2019, after President Jair Bolsonaro took office, the Office of the Comptroller General remodelled part of its internal structure, gained a new secretariat for fighting corruption, and renamed the Secretariat for Corruption Prevention to Secretariat for Transparency and Corruption Prevention (Brazilian Presidency, 2019). The changes made did not necessarily improve the governmental agencies' disciplinary systems or enforce an anti-corruption culture across agencies. On the contrary, the new structure closed down the Office of the Comptroller General's sectoral inspectorates (corregedorias setoriais), responsible for monitoring the flow, quality, and efficiency of disciplinary procedures in each ministry and respective bodies individually. There are now three coordinators responsible for controlling the entire disciplinary system by 'topics' (admissibility of evidence, disciplinary procedures, and promoting the system's integrity).

And yet, not every agency has a formal department with workers exclusively dedicated to investigating malpractice and analysing disciplinary cases. In May 2017, for example, 231 agencies were under the Office of the Comptroller General's supervision but only $22 \%(n=51)$ of them had their own internal affairs departments (corregedorias seccionais).

Although the Office of the Comptroller General has become a key rule maker and supervisor of the bureaucratic accountability process over time, it has never been active in carrying out investigative procedures in each and every agency. Civil servants have been expected to monitor and recommend administrative penalties against their peers in their respective governmental bodies. In special cases, depending on the defendant and on the circumstances, the Office of the Comptroller General can lead the investigation instead of the agency where the civil servant allegedly committed the misconduct. In addition, administrative procedures in Brazil run in parallel with court cases against both career and politicallyappointed civil servants. This means that corrupt agents have to be prosecuted independently by both administrative committees and judicial courts. Administrative and court procedures are completely independent, but they abide by the same legal infrastructure and all evidence collected in one proceeding can be used in the other.

The mechanisms created to investigate and punish civil servants administratively have an essentially reactive incident-oriented function (Macaulay, 2002). There are many possible motivations for opening a procedure within the disciplinary system, but the reason is never recorded. To report any misconduct, the alleged offences can be detailed in writing by anyone, including citizens, other civil servants or representatives from external accountability agencies. News reported by the media is also considered. Although anonymous allegations are officially accepted, interviewees reported that they tend not to be prioritised.

An Administrative Disciplinary Procedure (Procedimento Administrativo Disciplinar) can only be opened after collection of evidence indicating that the offence did indeed take place. In this case, a temporary committee with three members-civil servants at the same or higher rank than the defendant, preferably from the same agency-is called in to analyse whether the federal 
civil servant has committed irregularities in the performance of his or her duties, and to suggest punishments. Witnesses should be called and every opportunity given to the civil servant to defend himself or herself while receiving legal counsel. The committee has up to 120 days to finish the report, but cases can be prolonged.

Penalties vary from a warning to suspension and/or fines for less severe offences (see Supplementary File). In the case of serious misconduct, such as corruption, the penalties are dismissal, demotion, or cancellation of pension-all three considered 'capital punishment' by the bureaucracy. If they are considered appropriate by the committee, the final report is sent for approval or rejection to the cabinet minister responsible for the agency where the investigation took place. It is always possible to appeal to the courts, given that the judiciary has the final word on whether to uphold the sanction or reinstate the civil servant.

\section{Empirical Analysis}

An administrative penalty is not a new tool for deterring bureaucratic misconduct. In Brazil, however, it has been used to an increasing extent, especially against acts of corruption. Between 2003 and 2014, the number of civil servants working for the Brazilian federal government increased by $18 \%$ (from 485,980 to 572,434 ). The number of disciplinary procedures that resulted in civil servants being punished with dismissal, demotion or cancellation of pension also increased each year-from 268 in 2003 to 429 in 2014, a $60 \%$ increase.

As Figure 1 illustrates, in Brazil the number of sanctions enacted in response to acts of corruption has varied moderately from year to year, although overall, $68.5 \%$ of the total of 5,005 punishments enforced between January 2003 and November 2014 were related to corruption. Figure 1 exclusively highlights the growth and

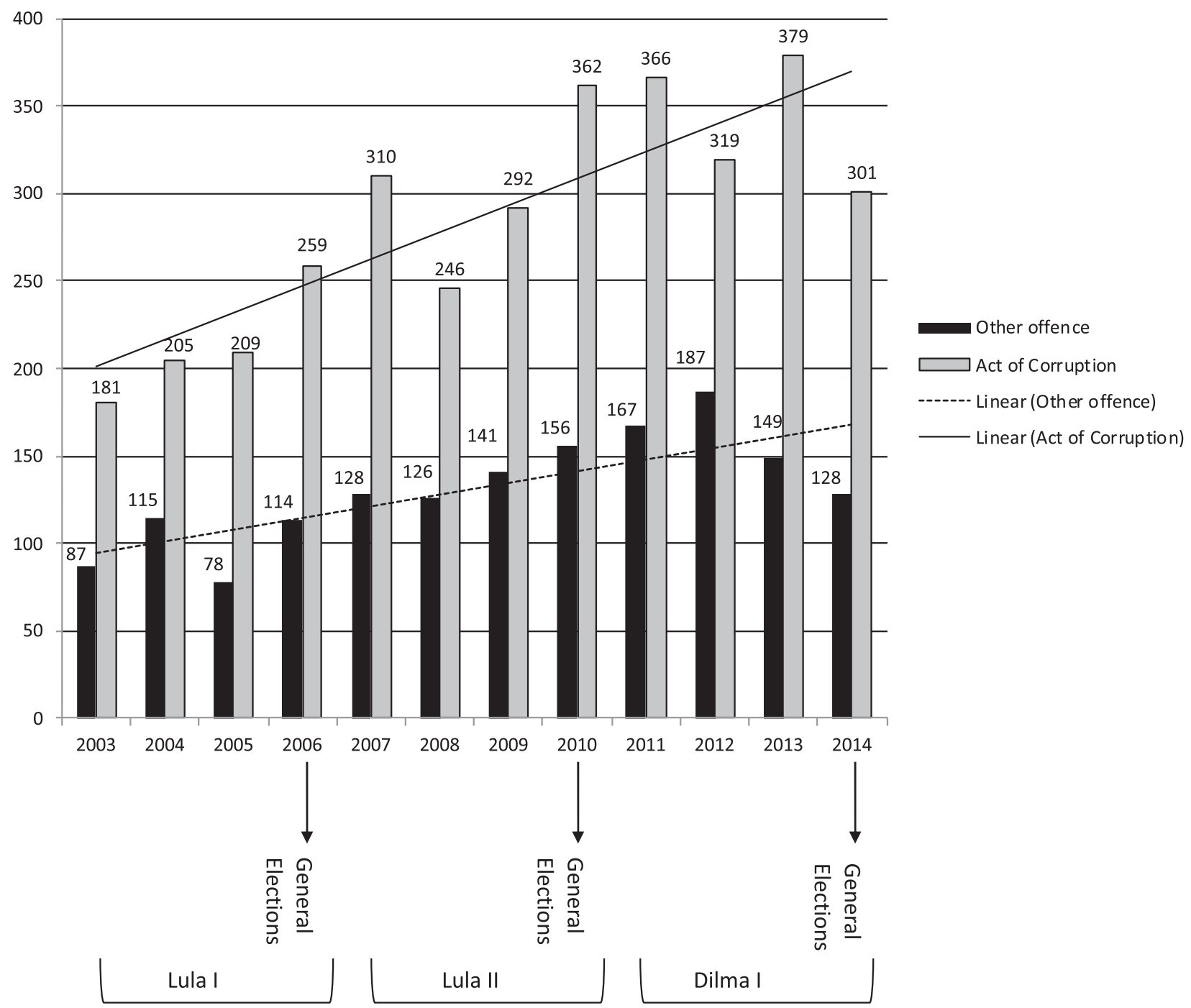

Figure 1. Distribution of 'expulsive' sanctions applied to civil servants, January 2003-November 2014, and reason for punishment. Source: Author based on the Office of the Comptroller General (2014). N =5,005 (penalties enforced from January 2003-November 2014). Notes: The classification 'act of corruption' is based on the Office of the Comptroller General's typology of corruption. 
uneven distribution of sanctions over time and shows that corruption-related sanctions increased more rapidly than those enforced for other serious offences. Data collected does not support the assumption that punishment increased rapidly because the number of punitive procedures for corruption also increased. In fact, after a rapid increase between 2008 and 2010, overall figures show a decrease in the number of procedures being opened. This is particularly the case for Ordinary Cause Administrative Disciplinary Procedures, initiated in response to more serious offences, including corruption.

The Ministries of Social Security, Justice, Education, Health, and Finance ranked highest for all penalties enforced. The number of sanctions imposed within a governmental body was not proportional to the size of its workforce. The Ministries of Social Security and Justice, for example, accounted for over $40 \%$ of all dismissals, although they comprised only $13 \%$ of the federal workforce combined. The agencies that exhibited a lower propensity to enforce penalties for cases of cor- ruption include the Ministries of Health and Education. These two together accounted for about $56 \%$ of the total workforce, but only $26 \%$ of the 'expulsive' sanctions enforced (see overall figures on the size of workforce, wage costs, and number of sanctions enforced in the Supplementary File).

Although there were a rapid increase and a greater number of sanctions imposed for corruption than for other serious administrative offences overall, Figure 2 illustrates a great variation across ministries in the proportion of penalties endorsed, including those related to corruption. On the one hand, the Ministry of Education, which encompasses all federal universities, had a total of 766 sanctions, $81 \%$ of them for other serious offences not related to corruption. On the other hand, the Ministry of Environment enforced 206 sanctions, 94\% of them related to corruption. The Ministry of Social Development, in turn, enforced zero sanctions, and the Ministries of Foreign Affairs and Tourism one sanction each in the period under analysis.

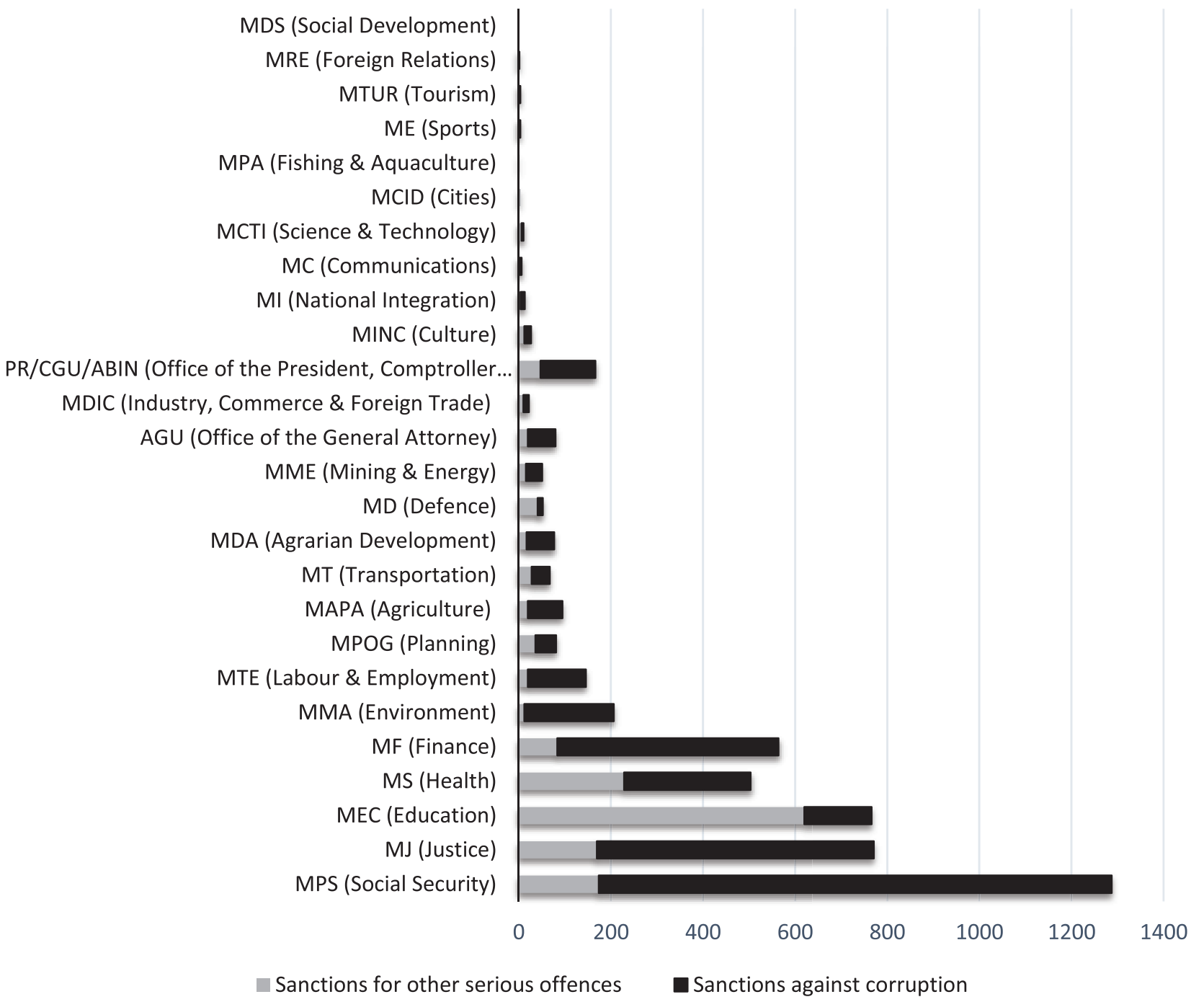

Figure 2. Number of sanctions for corruption-related and other serious offences enforced per Ministry, January 2003November 2014. Source: Author's based on the Office of the Comptroller General (2014). 
When analysing where punished acts of misconduct took place most commonly, the Institute for Social Security ranked first as the governmental body that enforced the largest number of sanctions. This institute, under the administrative structure of the Ministry of Social Security, enforced 1,282 penalties alone, $87 \%$ for corruption-related acts. The federal universities combined ranked second with a total of 593 sanctions, $84 \%$ of them for other serious offences not related to corruption. The Traffic Police, under the structure of the Ministry of Justice, ranked third: 417 penalties enforced, $90 \%$ related to acts of corruption.

Interviews complemented the statistical analysis and were helpful in shedding light on a complex issue: The degree to which a civil servant is exposed to opportunities for corruption might vary not only according to the task to which he or she is assigned but also according to how well internal and external controls function in certain agencies. This happens partly because the Office of the Comptroller General's role is still limited to setting overall standards and supervising the bureaucratic accountability process, and because not every agency has an internal affairs unit with dedicated and motivated personnel to analyse filed reports, collect initial evidence and/or conduct punitive procedures. The Office of the Comptroller General provides a multilateral capability to support high priority corruption cases without necessarily promoting the implementation of more efficient, better coordinated and faster operational measures for combating acts of misconduct in each and every agency. In other words, the Office of the Comptroller General has not managed to create its own anti-corruption enforcement culture ('willingness' to investigate/sanction) across other agencies.

From the interviews, three main themes emerged as a result of the attempt to explain the distribution of sanctions between the various agencies: (i) systemic opportunity vs. internal resources, (ii) embedded self-protective practices, and (iii) a convenient reliance on the web of accountability institutions.

\subsection{Systemic Opportunity vs. Internal Resources}

Most interviewees -18 out of 24 -seemed to perceive a clear difference between systemic opportunities for misconduct and the internal resources available to curb such behaviour, especially acts of corruption, which is directly linked to each governmental body, its role, and internal structure. In short, there is a perception that the level of effectiveness of inspectorates is more likely to impact on the number of sanctions enforced than the degree to which the bureaucrats in the agency in question are exposed to opportunities for misconduct by the nature of their work.

This proved to be the case in 7 out of the 10 bodies that enforced the greatest number of overall punishments ( $75 \%$ of all 5,005 sanctions enforced). The Institute for Social Security, the Traffic Police, the
Revenue Service, the Federal Police, the National Health Foundation, the Institute of the Environment and the Labour Offices have workers with a high level of corruption opportunity, but also have long-established (from late 1990s/mid-2000s) and well-structured internal affairs units. These have dedicated personnel who are carefully selected and receive incentives to investigate and recommend sanctions (such as top-up salaries or the option of being transferred to any other state after a certain period of time). They are also among the agencies that recommend more sanctions for corruption (over 67\%) than for other serious offences.

In contrast, the Ministries of Health and Education, which only created general internal affairs units with permanent staff in 2013 and 2017 respectively, enforced more sanctions against other serious offences than corruption from 2003 to 2014. Jesus Filho (2016), Deputy Inspector in the Ministry of Health, touches on the topic of enforcement willingness when he highlights that before the creation of a centralised structure within the Ministry of Health, managers in federal hospitals and institutes were responsible for opening disciplinary procedures but perceived the investigations as negative: "Many managers were averse to these procedures. To them, they make operational, administrative, and managerial issues explicit. Hence, some files were sent to the archive or stand still without investigation" (Jesus Filho, 2016, p. 12).

The outlier is the Ministry of Finance, which managed to create, from scratch, an inspectorate that started with four civil servants in 2013, and four years later had a team of 55-some of them receiving top-up salaries-working on different and very well-organised tasks. Sanctions for corruption also rapidly increased in the Ministry of Finance. The head of its disciplinary unit sat the formal exam to work for the Office of the Comptroller General and was then re-allocated to occupy a position of trust in the Ministry of Finance, establishing the fight against corruption as a priority. Interviewee 23 , who works in the Ministry of Finance's internal affairs unit, highlights the importance of being independent at the same time as receiving political support from the top in order to improve internal disciplinary control.

Most of the interviewees believed that the absence of well-structured internal affairs units increases the likelihood of civil servants being personally responsible for opening and conducting procedures against their direct or former colleagues, which is likely to increase the constraints and the costs for them. This happens because members of disciplinary committees can be civil servants randomly selected to conduct punitive procedures. In theory, they cannot decline the task, except in cases of family or personal links, although it is very common for a civil servant to decline by presenting medical statements or a note signed by the civil servant's direct manager.

However, the data suggest that the mere existence of an internal affairs unit and the fact that a governmental 
body has high capacity in terms of general professionalisation and resources does not guarantee that there will be a high number of sanctions. Although meritocratic recruitment, a predictable bureaucratic career ladder, and relatively high salaries may increase competence and corporate coherence, in the case of the Ministry of Foreign Affairs it did not result in a high number of disciplinary procedures. In fact, between 2003 and 2014, only one civil servant - not a career diplomat but a lower-ranking administrative official-was dismissed. Among integrity enforcers, the Ministry of Foreign Affairs is known as a governmental body where self-protective behaviour prevails when it comes to internal accountability and controls. For Brazilian diplomats, the perceived costs of maximising accountability are extremely high, especially because personal connections and maintaining cordial relations with superiors are very important for promotion and career advancement.

Interviewee 7, who helped to design disciplinary mechanisms and has expertise in conducting administrative procedures, explicitly linked the low level of penalties to a self-protection strategy in certain agencies. He implied that administrative discretion is also used to decide who is investigated and who is not, based on criteria that lie beyond legal requirements and internal structures. He also used the term "sausage factory" to describe how an administrative disciplinary procedure is carried out, because "you put whatever you want inside it" - meaning that there is great scope to exercise discretion and that the quality of the work carried out by investigative committee members varies greatly.

\subsection{Embedded Self-Protective Practices}

The majority of the interviewees were quite open in stating that they find the task of conducting investigations embarrassing, and stressed that professional, and physical, proximity to the defendant makes it especially difficult-by proximity they meant not only having a close relationship but also sharing the workplace or having already worked together. For example, several cited the uncomfortable scenario of encountering the target of an investigation every day, walking down the corridor or in the elevator. Interviewees also perceived the pursuit of absolute integrity as very costly in both monetary and non-monetary terms, although they recognised it as their duty to hold peers accountable.

Interviewee 17, for example, stressed that, although he works for the Traffic Police, he has been invited to conduct "over 400 disciplinary procedures in different agencies" because he is among the few civil servants who actually "like and know how" to investigate bureaucrats for corruption. In the Office of the Comptroller General, as one would expect from an anti-corruption agency, the embarrassment of investigating or punishing colleagues is felt to be less intense once a correctional unit has been established, with civil servants selected specifically to carry out disciplinary actions.
Corruption-related procedures are considered to generate more constraints and are perceived as costlier even for those working in disciplinary units. Interviewee 21 , permanently allocated to the inspectorate of a governmental body, admitted he does not like being involved in the investigation of corruption cases "because [he does] not have the right tools or knowledge" to carry them out. He also stated that most of the time he sees himself more as a social worker, trying to help people save their jobs when the suspicions against them are not based on concrete evidence, or when they cause psychological or other health issues.

Only two interviewees directly used the word corporativismo, meaning self-protective behaviour, to explain the embarrassment experienced by civil servants targeting their peers. But many of them highlighted that the greater the proximity of the investigator to the individual under investigation, the greater the discomfort. Interviewee 1, a career civil servant at the Office of the Comptroller General, recognised that those creating the norms and internal mechanisms aimed at improving accountability have diagnosed the problem of selfprotective behaviour. To try to circumvent the embarrassment involving those workers who often share loyalty, a stock database of the presidents of administrative investigative procedures and the other members was created to be shared among agencies and avoid the 'proximity factor'. He admits the database of civil servants willing to be part of the Administrative Disciplinary Procedures' committee has not been working properly.

There was also a consensus-23 out 24 interviewees - that imposing discipline through investigation and punishment is not a task for everyone. There are certain personality types who are liable to jeopardise the procedure, whether by seeking to protect the accused or, at the other extreme, by taking an excessively severe approach. However, there was no consensus about what the right personality for investigating peers would be. Most interviewees agreed that it is not necessary to have a legal background, and that the suitable person should not have 'blood in their eyes' or be over-emotional. The incentives the interviewees considered effective were financial rewards and the offer of a transfer to another agency after the investigation has been concluded.

\subsection{A Convenient Reliance on the Web of Accountability Institutions}

The majority of the interviewees referred to 'easier' and/or 'faster' procedures, mainly those involving the efficient collection of evidence by other external actors within the web of accountability such as the Federal Police and the Prosecution Service. Some of them admitted that these easier procedures are prioritised and are more likely to be concluded quickly. On the other hand, few interviewees openly said that easy targetsincluding individuals with little power-are prioritised. Interviewee 16 openly admitted that rational choices are 
made in the real world when investigating and punishing civil servants, and used cost-benefit vocabulary such as 'maximise the outcome':

Ideally, from the legal perspective, no irregularity could take place without being investigated. [But] in the real world we do have scarce resources, which makes it necessary to prioritise. And prioritisation will require a strategy of action. It is evident that if we have fewer resources the idea is to maximise the outcome. Actually, if we have a situation in which the collection of evidence is strong, as in the Federal Police operations, or in which there are more robust elements or the amount of money [involved] is higher...the outcome of one single case can be the same as hundreds of others. This needs to be our strategy. The [key] elements...investigation by the police, higher position of trust, large amounts of money, the involvement of more than one agency, are a consequence of the need to prioritise....We do not have the structure to investigate everything. (Interviewee 16, who monitors the disciplinary system from the Office of the Comptroller General)

The high level of dependence on the web of accountability institutions also impacts on the overall figures for sanctions. Interviewee 13 , for example, clarified how the practice of internal disciplinary control is connected to, and in a way dependent upon, the multi-organisational accountability system. As an example, she said that most of the Institute of the Environment's disciplinary procedures are opened after operations by the Federal Police. For her, "it makes things much easier. The [disciplinary] procedure is much faster, the search for evidence will not be such a complex task for the committee." According to her, when there is nothing solid to open an administrative investigation, integrity enforcers go first to the police.

\section{Discussion and Conclusion}

This exploratory study was an attempt to uncover the dynamics of the official response to bureaucratic corruption, combining descriptive statistics on the distribution of administrative penalties and semi-structured interviews that captured the perception of integrity enforcers. The executive branch in Brazil and its government workers were used as a case study. Despite the rapid growth in penalties, in particular those for corruption, an enduring resistance to making the fight against corruption a top priority in their respective bodies was observed among most integrity enforcers - the exception, as expected, is the Office of the Comptroller General, the anticorruption agency within the Brazilian federal executive.

The findings show great cross-agency diversity in corruption-control mechanisms. The data indicate that penalties for corruption are highly concentrated in a few agencies-sanctions recommended by the Institute for
Social Security, the Traffic Police and the Ministry of Finance together account for $51 \%$ of the 3,429 penalties for corruption enforced in the period under analysis. Overall, participants considered corruption-related procedures more complex to investigate and, accordingly, they are perceived by those responsible for holding their peers accountable as costlier than those related to other administrative offences. The findings also suggest that agencies with well-established internal affairs units are more likely to enforce sanctions against corruption. This is because they often have more specialised and motivated staff available to select and evaluate the material evidence before opening procedures, and to form part of the disciplinary committees that conduct the investigations. Having a skilled integrity enforcer is as important as having a civil servant who is willing and not embarrassed to enforce the law against his or her own peers.

This particular set of findings complements Gingerich's (2013) insights into the Brazilian bureaucracy. He identified a large variance in the perception of corruption control mechanisms in the Brazilian bureaucracy when measuring institutional politicisation and partisan exploitation. While Gingerich associates dysfunctional agencies with political pressures, this study identifies a link between the variance in sanctions enforced and low incentives, perceived constraints and costs related to the disciplinary work, particularly in the case of corruption-related procedures. Although a few interviewees were quick to mention political pressures, they were not portrayed as being more significant constraints than individual reluctance, self-seeking behaviour or institutional incapacity.

Because of factors other than the actual wrongdoing that they are tasked with investigating, these integrity enforcers use discretion in exercising their official authority, so as to reduce difficulty and inconvenience from their own perspective. If, for whatever reason, integrity enforcers perceive formal laws, rules, and procedures as detrimental and/or costly for them personally, they might circumvent them. In addition, the relationship between anti-corruption agencies like the Office of the Comptroller General and the web of enforcers within ministries is a key issue that has been neglected so far by the literature on anti-corruption agencies. This article found evidence that the disciplinary reforms that have taken place in Brazil, especially with the creation of the Office of the Comptroller General, have not established a fully operational horizontal accountability system within the executive. As observed in the reforms that have brought about the transition from patronage to merit-based civil service systems (Geddes, 1994; Grindle, 2012), new disciplinary rules are resisted and often subverted.

The chances are high that integrity enforcers will be reluctant and/or selective when it comes to starting an internal investigation, particularly in corruption-related cases. The findings also suggest that where accountability is openly pursued to the fullest extent, it is more 
likely to lead to a higher number of sanctions. However, it is more likely that a situation of 'convenient accountability' exists, with agencies heavily conditioned by external actors of horizontal accountability, and/or fewer penalties being enforced. With convenient accountability, there are more perceived constraints, fewer incentives and, therefore, more room for collusion between agents, as observed in the Brazilian case.

The findings presented here show that anticorruption agencies should be more active and more present within each disciplinary unit, in order to improve motivation and put the anti-corruption narrative into practice. In addition, public policies should focus on creating incentives for civil servants to monitor their peers. Accountability is more likely to be more objective and powerful with an internal affairs department in each governmental body and higher professional standards for the internal affairs units with specific requirements for the job.

The Brazilian case indicates that the likelihood of misconduct being investigated and punished, particularly in cases of corruption, can be increased by the existence of a long-term and well-structured internal affairs unit in governmental bodies, a perception of fewer impediments on the part of the integrity enforcers enforcing the sanctions, and the actions of external actors of the accountability system. Due to the limited data available, further research is needed to provide information on the capacity to enforce sanctions, on the ministries' exposure to the risk of corruption, and on external procedures that motivate the opening of an internal investigation or are used to punish both criminally and administratively civil servants. Further research should explore the characteristics of those who have been punished, their political affiliation, their proximity to the integrity enforcers, and the time elapsed between the start and the conclusion of the procedures.

More robust models of convenient accountability and of the willingness to enforce internal control should also be tested by future research. From what we have learned, self-policing is possible and some governmental bodies are performing better than others in overseeing and punishing bureaucratic misconduct. But to be more effective, the control of bureaucratic corruption should become less reactive to external demands. In this way, accountability may become more inconvenient-for those who break the law as well as for integrity enforcers-and therefore less selective, and more powerful and productive.

\section{Conflict of Interests}

The author declares no conflict of interests.

\section{Supplementary Material}

Supplementary material for this article is available online in the format provided by the authors (unedited).

\section{References}

Alt, J. E., \& Lassen, D. (2014). Enforcement and public corruption: Evidence from the American States. The Journal of Law, Economics, \& Organization, 30(2) 306-338.

Anechiarico, F., \& Jacobs, J. B. (1996). The pursuit of absolute integrity: How corruption control makes government ineffective. Chicago, IL: University of Chicago Press.

Becker, G. S., \& Stigler, G. J. (1974). Law enforcement, malfeasance, and the compensation of enforcers. Journal of Legal Studies, 3(1), 1-19.

Bersch, K., Praça, S., \& Taylor, M. M. (2016). Bureaucratic capacity and political autonomy within national states: Mapping the archipelago of excellence in Brazil. In M. Centeno, A. Kohli, D. Yashar, \& D. Mistree (Eds.), States in the developing world (pp. 157-183). Cambridge: Cambridge University Press.

Bovens, M. (2007). Analysing and assessing accountability: A conceptual framework. European Law Journal, 13(4), 447-468.

Boyatzis, R. E. (1998). Transforming qualitative information: Thematic analysis and code development. London: Sage.

Brazilian Presidency. (2019). Decree 9681/2019. Retrieved from http://www.planalto.gov.br/ccivil_03/ _Ato2019-2022/2019/Decreto/D9681.htm

Brennan, G., \& Buchanan, J. M. (1985). The reason of rules: Constitutional political economy. Cambridge: Cambridge University Press.

Bryman, A. (2008). Social research methods. Oxford: Oxford University Press.

Dahlström, C., Lapuente, V., \& Teorell, J. (2012). The merit of meritocratization: Politics, bureaucracy, and the institutional deterrents of corruption. Political Research Quarterly, 65(3), 656-668.

Davis, J. (2004). Corruption in public service delivery: Experience from South Asia's water and sanitation sector. World Development, 32(1), 53-71.

Fielding, N., \& Thomas, H. (2001). Qualitative interviewing. In N. Gilbert (Ed.), Researching social life (2nd ed., pp. 123-143). London: Sage.

Fjeldstad, O. H. (2003). Fighting fiscal corruption: Lessons from the Tanzania revenue authority. Public Administration and Development, 23(2), 165-175.

Fleisher, D. (2002). Corruption in Brazil: Defining, measuring, and reducing (Report of the CSIS Americas Program). Washington, DC: The CSIS Press.

Fox, J. A. (2007). Accountability politics: Power and voice in rural Mexico. Oxford: Oxford University Press.

Gans-Morse, J., Borges, M., Makarin, A., Mannah Blankson, T., Nickow, A., \& Zhang, D. (2018). Reducing bureaucratic corruption: Interdisciplinary perspectives on what works. World Development, 105, 171-188.

Geddes, B. (1994). Politician's dilemma: Building state capacity in Latin America. Berkeley, CA: University of California Press. 
Gingerich, D. (2013). Political institutions and partydirected corruption in South America: Stealing for the team. Cambridge: Cambridge University Press.

Grindle, M. S. (2012). Jobs for the boys: Patronage and the state in comparative perspective. Cambridge, MA: Harvard University Press.

Huntington, S. P. (1989). The trilateral crisis of democracy. Executive Intelligence Review EIR, 16(21).

Jesus Filho, O. (2016). A implantação da CorregedoriaGeral do Ministério da Saúde: Discutindo mudanças no campo da gestão [The implementation of the Internal Affairs Department at the Ministry of Health: Discussing changes in the field of management] (Doctoral dissertation). University of Brasília, Brasília, Brazil.

Johnston, M. (2005). Syndromes of corruption: Wealth, power and democracy. Cambridge: Cambridge University Press.

Laffont, J. J., \& Meleu, M. (1997). Reciprocal supervision, collusion and organizational design. The Scandinavian Journal of Economics, 99(4), 519-540.

Laffont, J. J., \& Rochet, J. C. (1997). Collusion in organizations. The Scandinavian Journal of Economics, 99(4), 485-495.

Loughry, M., \& Tosi, H. (2008). Performance implications of peer monitoring. Organization Science, 19(6), 876-890.

Loureiro, M. R., Abrucio, F. L., \& Pacheco, R. S. (Eds.). (2012). Burocracia e política no Brasil: Desafios para a ordem democrática no século XXI [Bureaucracy and politics in Brazil: Challenges to the new democratic order in the 21st century]. Rio de Janeiro: FGV Editora.

Macaulay, F. (2002). Problems of police oversight in Brazil (Working Paper CBS-33-02). Oxford: University of Oxford Centre for Brazilian Studies.

Mainwaring, S., \& Welna, C. (Eds.). (2003). Democratic accountability in Latin America. Oxford: Oxford University Press.

March, J. G., \& Olsen, J. P. (1989). Rediscovering institutions: The organizational basis of politics. New York, NY: Free Press.

Meyer-Sahling, J. H., \& Mikkelsen, K. S. (2016). Civil service laws, merit, politicization, and corruption: The perspective of public officials from five East European countries. Public Administration, 94(4), 1105-1123.

O’Donnell, G. (1999). Horizontal accountability in new democracies. In A. Schedler, L. Diamond, \& M. Plattner (Eds.), The self-restraining state: Power and accountability in new democracies (pp. 29-52). London: Lynne Rienner Publishers.
Office of the Comptroller General. (2014). Administrative Penalties and Reinstatements Enforced from January 2003 to November 2014 [Datafiles and codebooks]. Unpublished raw data.

Oliveros, V., \& Schuster, C. (2017). Merit, tenure, and bureaucratic behaviour: Evidence from a conjoint experiment in the Dominican Republic. Comparative Political Studies, 51(6), 759-792.

Perry, J. L. (1996). Measuring public service motivation: An assessment of construct reliability and validity. Journal of Public Administration Research and Theory, 6(1), 5-22.

Perry, J. L., \& Hondeghem, A. (2008). Editors' introduction. In J. L. Perry \& A. Hondeghem (Eds.), Motivation in public management: The call of public service (pp. 1-14). Oxford: Oxford University Press.

Portal da Transparência Brasil. (2020). Cadastro de Expulsões da Administração Federal [Register of Sanctions Resulting in Expulsions within the Federal Administration]. Portal da Transparência. Retrieved from www.portaltransparencia.gov.br/sancoes/ ceaf?ordenarPor $=$ nome \&direcao $=$ asc

Power, T., \& Taylor, M. (Eds.). (2011). Corruption and democracy in Brazil: The struggle for accountability. Notre Dame, IN: University of Notre Dame Press.

Rauch, J. E., \& Evans, P. (2000). Bureaucratic structure and bureaucratic performance in less developed countries. Journal of Public Economics, 75(1), 49-71.

Rose-Ackerman, S. (1978). Corruption: A study in political economy. New York, NY: Academic Press.

Salganik, M. J., \& Heckathorn, D. D. (2004). Sampling and estimation in hidden populations using respondent-driven sampling. Sociological Methodology, 34(1), 193-240.

Stiglitz, J. E. (1990). Peer monitoring and credit markets. The World Bank Economic Review, 4(3), 351-366.

Tirole, J. (1993). Collusion and the theory of organizations. In J. Laffont (Ed.), Advances in economic theory: Sixth world congress (pp. 151-213). Cambridge: Cambridge University Press.

Treisman, D. (2000). The causes of corruption: A crossnational study. Journal of Public Economics, 76(3), 399-457.

van Rijckeghem, C., \& Weder, B. (2001). Bureaucratic corruption and the rate of temptation: Do wages in the civil service affect corruption, and by how much. Journal of Development Economics, 65(2), 307-331.

Vasconcellos de Figueiredo, F. O. (2016). Building up a convenient accountability: How the 'anti-corruption' law in Brazil was put into force. Brasiliana: Journal for Brazilian Studies, 4(2), 550-578. 


\section{About the Author}

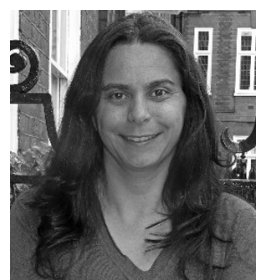

Fernanda Odilla is a Researcher and obtained her PhD at the Brazil Institute at King's College London. She has an MA in Criminology and Criminal Justice from King's College London, a pre-MA in Crime and Public Safety from the Federal University of Minas Gerais, and a BA First Class Honours in Journalism from the Pontifical Catholic University of Minas Gerais. Her research interests include corruption and anti-corruption studies, accountability, integrity and governance. 